\title{
Species ratio in the complex of the cruciferous bugs and seasonal dynamics of the population number
}

\author{
S.V. Stankevych ${ }^{1^{*} \mathbb{D}}$, M.D. Yevtushenko ${ }^{1}$ D , V.V. Vilna ${ }^{1 D}$, A.V. Matsyura ${ }^{2}$, I.V. Zabrodina ${ }^{1}$, \\ I.P. Lezhenina 1D, H.V. Baidyk 1D, M.O. Filatov ${ }^{1 D}$, L.Ya. Sirous ${ }^{1}$, D.D. Yushchuk ${ }^{1 D}$, \\ V.O. Melenti ${ }^{1 D}$, N.V. Lutytska ${ }^{1 D}$, Yu.O. Kolomiiets ${ }^{1 D}$, O.A. Molchanova ${ }^{1 D}$ \\ 'V.V. Dokuchaiev Kharkiv National Agrarian University, v. Dokuchaevske, Kharkiv region, 62483, Ukraine \\ ${ }^{2}$ Altai State University, Barnaul, Russian Federation \\ *Corresponding author E-mail: sergejstankevich1986@gmail.com \\ Received: 10.12.2020. Accepted 28.01.2021
}

\begin{abstract}
The complex of cruciferous bugs includes such species as painted or harlequin (cabbage) bug (Eurydema ventralis Kol), pentatomid rape bug (E. oleraracea L.), and mustard bug (E. ornata L.). They belong to a line Hemiptera, the family Shield bugs (Pentatomidae), and the genus Cruciferous bugs (Eurydema). The dominant species is the cabbage bug. The mustard bug dominated only in 2007, and since 2012 it has not been detected in the records. They are widespread throughout the whole territory of Ukraine. Both adult bugs and larvae damage the crops; they pierce the leaf skin or floriferous shoots with the proboscis and suck out the juice. The light spots appear at the puncture points, the tissue dies, falls out, and the irregular form holes are formed. When the seeds are damaged, the flowers and ovary fall off, and the seeds' quality deteriorates. The harmfulness of the bugs increases dramatically in dry and hot weather. We found out that the largest number of wintering bugs was concentrated in the forest belts, near which there were the crops of spring oilseeds and cabbage plants and the seeds of white cabbage. The density of wintering imagines of the cabbage bug was 1.7-4.4 specimens/ $\mathrm{m}^{2}$, and the density of the rape bug was $0.9-2.3$ specimens $/ \mathrm{m}^{2}$ of the forest floor. In the first turn, the wintered bugs' imagines populated the cabbage seeds as a trap crop, and then they populated the sprouts of spring rape and mustard. The density of the cruciferous bugs on the seeds of white cabbage of Kharkivska 105 variety was 19.0-30.7 specimens per plant at the beginning of the populating of spring oilseed cabbage crops at the Educational, Research and Production Centre "Research Field" of Kharkiv National Agrarian University named after V.V. Dokuchaiev (Ukraine). The maximum density of the cruciferous bugs in the phenophase of the yellow bud on the crops of spring oilseed cabbage plants was the following: $4.5 \pm 1.45$ specimens/ $\mathrm{m}^{2}$ of the cabbage bug was found on spring rape of Ataman variety, $4.0 \pm 1.83$ specimens $/ \mathrm{m}^{2}$ on white mustard of Carolina variety and $3.5 \pm 2.65$ specimens $/ \mathrm{m}^{2}$ on Chinese mustard of Tavrychanka variety; and the density of the rape bug was $0.7 \pm 0.23,0.5 \pm 0.23$ and $0.5 \pm$ 0.3 specimens $/ \mathrm{m}^{2}$ respectively. The maximum density of the cruciferous bugs in the phenophase of the yellow bud on spring rape of Ataman variety was $6.0 \pm 0.9$ specimens $/ \mathrm{m}^{2}$, on white mustard of Carolina variety it was $5.7 \pm 0.85$, on Chinese mustard of Tavrychanka variety, the average density was $5.3 \pm 0.9$ specimens $/ \mathrm{m}^{2}$ at the state enterprise "Research Farm "Elitne" (Ukraine). The highest number of cabbage and rape bugs at a density of 22.3-30.7 specimens/plant is concentrated on the seeds of white cabbage plants at noon, and the lowest number of them was found at 8.00 AM, and the density was 17.9-28.5 specimens/plant. The maximum density of 51-60 specimens/plant was at noon. We found out that the beginning of populating spring rape of Ataman variety by the bugs that occurred in the phenophases of 3-4 pairs of true leaves, namely during the rosette formation. The larval reappearance's beginning took place when the sum of the active temperatures was $520-688{ }^{\circ} \mathrm{C}$ (from the end of the third decade of April to the beginning of May's third decade when the sum of the active temperatures was $106-412{ }^{\circ} \mathrm{C}$ ). We observed the peak of the cruciferous bugs' number from the second and third decades of June to the third decade of July, depending on the year's climatic conditions. The highest density of the bugs was observed before harvesting. Keywords: spring rape, mustard, pests, cruciferous bugs.
\end{abstract}




\section{Introduction}

The complex of cruciferous bugs includes such species as painted or harlequin (cabbage) bug (Eurydema ventralis Kol), pentatomid rape bug (E. oleraracea L.), and mustard bug (E. ornata L.). They belong to a line Hemiptera, the family Shield bugs (Pentatomidae), and the genus Cruciferous bugs (Eurydema). The cruciferous bugs are a common species and are spread throughout the Palaearctic. They are widespread throughout the whole territory of Ukraine (Puchkov, 1961; Yevtushenko et al., 2016).

The imago of the cabbage bug is $6-10 \mathrm{~mm}$ long; its body is flattened, the prothorax is red with six black spots, on the shield and elytra there are black spots and stripes (Fig. 1); the antennae are 5-segmented; a triangle scutellum covers a larger part of the abdomen, the legs are 3-segmented. The mustard bug's imago is 6-10 mm in size; the body is flattened, the prothorax is yellow with six black spots, on the shield and elytra, there are black spots and stripes (Fig. 1). The imago of the rape bug is 6-10 mm in size; the body is flattened, the prothorax is white with six black spots and black spots and stripes (Fig. 1). The egg is 0.6-0.8 mm in size, cylindrical, and the bottom is rounded; the top is covered by a convex lid that opens when the larvae hatch (Figure 1). The larva of the imago is similar (Figure 1). The immature bugs overwinter under the fallen leaves at the edge of forest belts, in gardens and parks, on the beams slopes and roadsides. In April and May, they leave the wintering places. Also, they feed on the cabbage weeds, and with the emergence of the cultivated cabbage sprouts and the transplanting of the seedlings, the bugs' mass flies over to them. The female lays 12 eggs in a group, placing them in two rows, more often on the leaves' underside. The fertility is up to 300 eggs. The embryonic development lasts for 6-12 days. The larvae feed on the plants for $25-40$ days turning into an adult insect. After the extra feeding, the bugs give birth to the second generation, which develops in July and August. Both the adult bugs and larvae damage the crops; they pierce the leaf skin or floriferous shoots with the proboscis and suck out the juice. The light spots appear at the puncture points, the tissue dies, falls out, and the irregular form holes are formed. When the seeds are damaged, the flowers and ovary fall off, and the seeds' quality deteriorates. The economic threshold of harmfulness is 2-3 bugs per plant (Puchkov, 1961; Yevtushenko et al., 2009; Stankevych, Vilna, 2012; Vilna, 2013; Vilna, Stankevych, 2013; Stankevych, Kava, 2013; Yevtushenko, Vilna, 2014; Vilna et al., 2015; Stankevych, 2015; Yevtushenko et al., 2016).

\section{Materials and methods}

The cruciferous bugs' development was observed in the entomological insulators (sweep nets) made from the agricultural fiber. The pests were counted according to the generally accepted method (Omeliuta, 1986; Stankevych, Zabrodina, 2016), the statistical data analysis, the correlation analysis, and the variance analysis (Dospiekhov, 1985) were performed.

The collected entomological material was analyzed and systematized, and the species were identified at the Zoology and Entomology Department of Kharkiv National Agrarian University named after V.V. Dokuchaiev (Ukraine). The calculations were conducted every five days, beginning from the sprouts' appearance by mowing with the entomological catching net and visual counting to establish the cruciferous bugs' seasonal dynamics. On each crop, the insects were captured using an entomological catching net with 25 double sweeps (50 sweeps) at the Educational, Research and Production Centre "Research Field" (Kharkiv National Agrarian University named after V.V. Dokuchaiev); 100 double sweeps along two diagonals of the field were made at the state enterprise "Research Farm "Elitne" (the Institute of Plant Growing named after V.Ya. Yuriev of the National Academy of Agrarian Sciences of Ukraine) (Mehalov, 1968; Nikiforov, 1951; Omeliuta, 1986; Fassulati, 1971; Chaika, 2010; Stankevych, Zabrodina, 2016).

The settling of the overwintered bugs was determined in the field No 1 of the central forage crop rotation at the State Enterprise "Research Farm "Dokuchaievske" of Kharkiv National Agrarian University named after V.V. Dokuchaiev in spring 2013. In autumn, the field was sown with winter rape; there was little snow in winter, and the crops were almost completely lost. In spring, the entire field was overgrown with weeds, and the predominant species were hedge mustard of Lozeliiv and common winter cress. The mowing with the entomological catching net (three routes) was carried in the forest belt direction, which was stretched from the east to the west. There were three routes for the inspection. The first one was parallel to the forest belt, which was directed from the north to the south and was at a distance of 40-50 m from it, the second route was in the middle of the field, and the third one was parallel to the ring highway at a distance of $40-50 \mathrm{~m}$ from it.

The experimental plot under spring oilseed cabbage crops was divided in half across the crops to determine the priority of spring rape and mustard crops populating. The plots were separated by a defensive strip of $1.5 \mathrm{~m}$ wide. The seedlings were removed from the first days of their appearance, and this plot was kept without the plants. After the emergence of the rape and mustard seedlings, the seed cabbage crops were planted on this plot.

We used the data of the Rogan meteorological observation station, which is located directly on the territory of the Educational, Research and Production Centre "Research Field" of Kharkiv National Agrarian University named after V.V. Dokuchaiev to analyze the weather conditions and their influence on the harmfulness and the pests' development. 


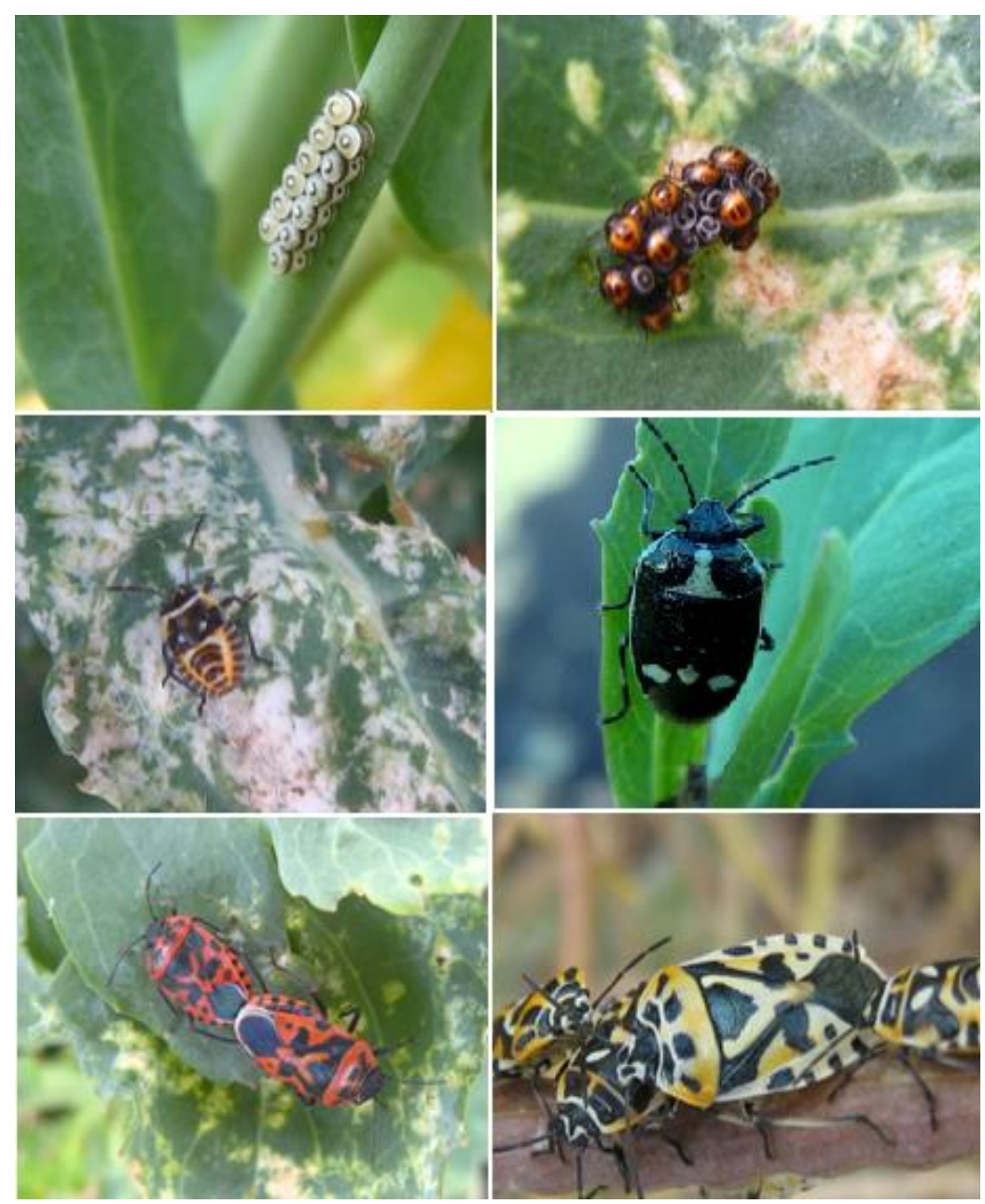

Fig. 1. Cruciferous bugs. 1. Oviposition; 2. Reappearance of larvae; 3. Larva and signs of damage; 4. Rape bug; 5. Mating of cabbage bugs; 6. Mustard bugs (photo by S. Stankevich, Educational, Research and Production Centre "Research Field" of Kharkiv National Agrarian University named after V.V. Dokuchaiev, 2018)

\section{Results and discussion}

According to our research in the Kharkiv region, there are all three types of cruciferous bugs common in Ukraine: cabbage, rape, and mustard bugs. The ratio between the cruciferous bugs' population on spring rape and mustard crops was not equivalent in experimental fields. Most often (in 2008-2010 and 2012-2014), the cabbage bug was the dominant species while the mustard bug dominated only in 2007; the rape bug was less numerous in all the years. During the seven-year studies, more or less cabbage and rape bugs annually populated spring rape and mustard. In the records of the "Research Field," the mustard bug on spring oilseed cabbage crops and white cabbage seedlings have not been found since 2012, though the overwintered cruciferous bugs usually populate these crops in the first turn (Table 1).

Table 1. Species ratio of cruciferous bugs on spring rape and mustard in 2007-2010 and 2012-2014

\begin{tabular}{|c|c|c|c|c|}
\hline \multirow{2}{*}{ Years } & \multirow{2}{*}{ Crop } & \multicolumn{3}{|c|}{ Species share in the complex of cruciferous bugs, $\%$} \\
\hline & & mustard bug & cabbage bug & rape bug \\
\hline \multirow{2}{*}{2007} & Spring rape & 83.8 & 12.2 & 4.0 \\
\hline & Mustard & 69.6 & 19.3 & 11.1 \\
\hline \multirow{2}{*}{2008} & Spring rape & 13.2 & 82.6 & 4.2 \\
\hline & Mustard & 27.5 & 67.1 & 5.4 \\
\hline \multirow{2}{*}{2009} & Spring rape & 40.4 & 55.3 & 4.3 \\
\hline & Mustard & 28.1 & 63.8 & 8.1 \\
\hline \multirow{2}{*}{2010} & Spring rape & 24.3 & 66.8 & 8.9 \\
\hline & Mustard & 9.1 & 78.7 & 12.2 \\
\hline \multirow{2}{*}{2012} & Spring rape & 0 & 85.2 & 14.8 \\
\hline & Mustard & 0 & 89.1 & 10.9 \\
\hline \multirow{2}{*}{2013} & Spring rape & 0 & 81.3 & 18.7 \\
\hline & Mustard & 0 & 91.4 & 8.6 \\
\hline \multirow{3}{*}{2014} & Spring rape & 0 & 87.1 & 12.9 \\
\hline & Mustard & 0 & 90.6 & 9.4 \\
\hline & $\sum$ average & 21.14 & 69.32 & 9.54 \\
\hline
\end{tabular}


The cruciferous bugs at the stage of the immature imago overwinter under the fallen leaves, in the parks and forest edges, on the beam slopes the roadsides, and in the gardens of Kharkiv and the Kharkiv region.

On April 13,2012, during the forest plantations' inspections, the first bugs after their awakening were found around the experimental field in the forest floor and on the wild cabbage plants; their number was about one specimen $/ \mathrm{m}^{2}$ of the inspected area of the forest floor. In the experimental field, the bugs first populated the cabbage saplings, and on May 4, the bugs emerged on the rape and mustard crops in the phase of sprouting; the cabbage's imagines bug (Eurydema ventralis Kol.) were the first to populate the plants.

In 2013 the density of the bugs in the forest floor was 1,4 specimens $/ \mathrm{m}^{2}$, and the emergence of the cabbage and rape bugs imagines from the wintering places began on April 19; on May 1, the imagines populated the cabbage seeds even though there have already been $70 \%$ of rape and mustard seedlings (Tables 2,3 ).

In 2014 in the wintering places of the cruciferous bugs' inspection, about two specimens per $\mathrm{m}^{2}$ were found on the forest floor inspected area. The cruciferous bugs began to emerge on April 10 (Table 4).

Table 2. Development of cruciferous bugs on cabbage seeds in 2012-2013

\begin{tabular}{lcc}
\hline Bugs development & Dates \\
\hline Beginning of bugs emergence from wintering places & 2012 & 2013 \\
& 13.04 & 19.04 \\
Beginning of populating cabbage seedlings by bugs & 2.05 & 1.05 \\
Bugs mating on cabbage seedlings & 6.05 & 3.05 \\
The emergence of the first oviposition of bugs on cabbage seedling & 11.05 & 8.05 \\
Mass oviposition of bugs & 18.05 & 10.05 \\
Beginning of bugs larvae reappearance & 20.05 & 14.05 \\
The mass reappearance of bugs larvae & 26.05 & 19.05 \\
\hline
\end{tabular}

The cruciferous bugs were populating the cabbage seedlings since May 2, and on May 6, they have already been mating; that is, they have been feeding on cabbage for four days in 2012 (Table 2). The first ovipositions on the cabbage seeds were found in the records on May 11, and they were registered in significant numbers on May 18. A single larval reappearance began on May 20, and the mass one was on May 26.

Table 3. Development of cruciferous bugs on spring rape of Ataman variety in 2012-2014

\begin{tabular}{lccc}
\hline Bugs development & \multicolumn{3}{c}{ Dates } \\
& 2012 & 2013 & 2014 \\
\hline Beginning of bugs emergence from wintering places & 13.04 & 19.04 & 10.04 \\
Beginning of populating spring rape by bugs & 20.05 & 26.05 & 30.04 \\
Bugs mating on spring rape & 28.05 & 5.06 & 12.05 \\
The emergence of the first oviposition of bugs & 5.06 & 14.06 & 23.05 \\
Mass oviposition of bugs & 9.06 & 20.06 & 2.06 \\
Beginning of bugs larvae reappearance & 13.06 & 23.06 & 6.06 \\
The mass reappearance of bugs larvae & 18.06 & 28.06 & 13.06 \\
\hline
\end{tabular}

In 2013 the cruciferous bugs were populating the cabbage seedlings since May 1, and on May 3, the bugs mating was observed, and on May 8, the first oviposition was revealed. The mass oviposition has been taking place since May 10. In the second decade of May, the bugs' larvae began to reappear, and since May 19, there has been mass reappearance. In 2013 the cabbage and rape bugs were found on the crops of spring rape only on May 26, while on the cabbage seedlings, the bugs' larvae of the first and second generations have been already developing; in 2012, at the same time, the mass reappearance of the cruciferous bugs' larvae on the cabbage seeds has been taking place.

Judging by these data, we can conclude that the bugs prefer the cabbage seedlings despite the large assortment of fodder vegetation. This is evidenced by the priority of their populating, mating, oviposition, the reappearance of larvae, and further development of the young generation, which does not pass on to the seedlings and young oilseed cabbage crops. Thus by planting in fives and tens plants of seed cabbage on four sides of the field of spring rape and mustard, it is possible to determine the beginning of the buds emergence, their extra feeding, and further development, which is essential in the organization and conducting spraying of the oilseed cabbage crops with the insecticides if the economic threshold of harmfulness is exceeded. The density of the cruciferous bugs on spring rape and mustard crops varied significantly in 2012-2014; which may be because in 2013, the cabbage seedlings were planted near the rape and mustard crops, and in 2012 they were planted at a distance of about $1 \mathrm{~km}$ from these crops (Table 4). 
Table 4. The density of cruciferous bugs on spring rape and mustard crops according to main phenophases of their development in 2012-2014

Phenophases of the plants' development

The density of cruciferous bugs population (specimens $/ \mathrm{m}^{2}$ ) for the

\begin{tabular}{lccc} 
& \multicolumn{3}{c}{ years of researches } \\
& 2012 & $0.9-1.0$ & 2014 \\
\hline Sprouts emergence & $1.0-1.1$ & $1.9-2.1$ & $0.9-1.1$ \\
Phenophase of rosette & $2.3-3.1$ & $3.3-3.6$ & $2.1-2.8$ \\
Budding and flowering & $6.5-6.9$ & $5.9-6.3$ & $4.8-5.1$ \\
Pods formation and their growth & $10.2-12.1$ & $4.7-5.3$ \\
Ripening & $11.1-12.6$ & $6.1-6.9$ & P4.6-5.1 \\
\hline
\end{tabular}

From the data given in Table 4, in 2012-2014, in the phase of the sprouts emergence, the density of the cruciferous bugs on spring rape and mustard crops did not exceed 1,0 specimen $/ \mathrm{m}^{2}$. In 2021, beginning from the rosette phenophase, the bugs' density on spring rape and mustard crops was within the range of 2.3-3.1 specimens/m²; in 2013, the density was 1.9-2.1 specimens $/ \mathrm{m}^{2}$, and in 2014 it was 2.1-2.8 specimens $/ \mathrm{m}^{2}$. In 2012 in the phenophases of budding and flowering, their density was 6.5-6.9 specimens $/ \mathrm{m}^{2}$; in 2013, it was 3.3-3.6 specimens/ $\mathrm{m}^{2}$, and in 2014 it was 4.8-5.1 specimens/ $\mathrm{m}^{2}$. In $2012 \mathrm{during}$ the phenophases mentioned above, the bugs' number was higher, and they had nothing to feed on because the plants had become physiologically old. In 2012, in the phenophases of pod formation and growth, the density of the cabbage bugs was already 10.2-12.1 specimens/ $\mathrm{m}^{2}$, and in 2013 it was 5.9-6.3 specimens $/ \mathrm{m}^{2}$, which is almost two times less compared with 2012 , and in 2014 the density of the bugs was 4.7-5.3 specimens $/ \mathrm{m}^{2}$.

In 2012 the larvae of the second generation's cruciferous bugs reappeared in the phenophase of pod formation and partial ripening. Even though the pods of spring rape and mustard were already almost $90 \%$ dry, the bugs and their larvae continued to stay on the plants almost until harvesting. However, most larvae of the second generation's cruciferous bugs did not have time to complete their development on the rape and mustard before harvesting. Beginning from July 25 , after harvesting the crops of spring rape and mustard in the experimental field, the inspections of wild weeds from the cabbage family and the sprouts of the mustard seeds fall have been continued.

In the second half of September, due to the poorly harvested mustard crops, the sprouts of mustard seeds fall appeared on the plot, populated by the bugs and continuing the development and feeding until October 3, 2012. The mustard plants were developing till the phenophase of the flowering beginning and then were buried into the soil with a disc harrow on this plot. We found that the cruciferous bugs continued their development on common winter cress until the first strong frosts.

In 2013 the larvae of the cruciferous bugs almost entirely completed their development on the cabbage seeds, and after burying the plant residues into the soil, the bugs continued to develop on the sprouts of the mustard seeds fall and on common winter cress plants even at $0{ }^{\circ} \mathrm{C}$ at night. The bugs feeding on the mustard seeds were observed until October 22 , when the daily average temperature had already fallen to $0^{\circ} \mathrm{C}$.

The seasonal dynamics of the cruciferous bugs' number for the research years are presented in diagrams (Figs 2-4). We concluded that the lowest bugs density was in April and in the first decade of May. There was a gradual increase in bugs' number regardless of the year and the crop from the third decade of June until the crops ripening. It was mainly due to the reappearance of the larvae.

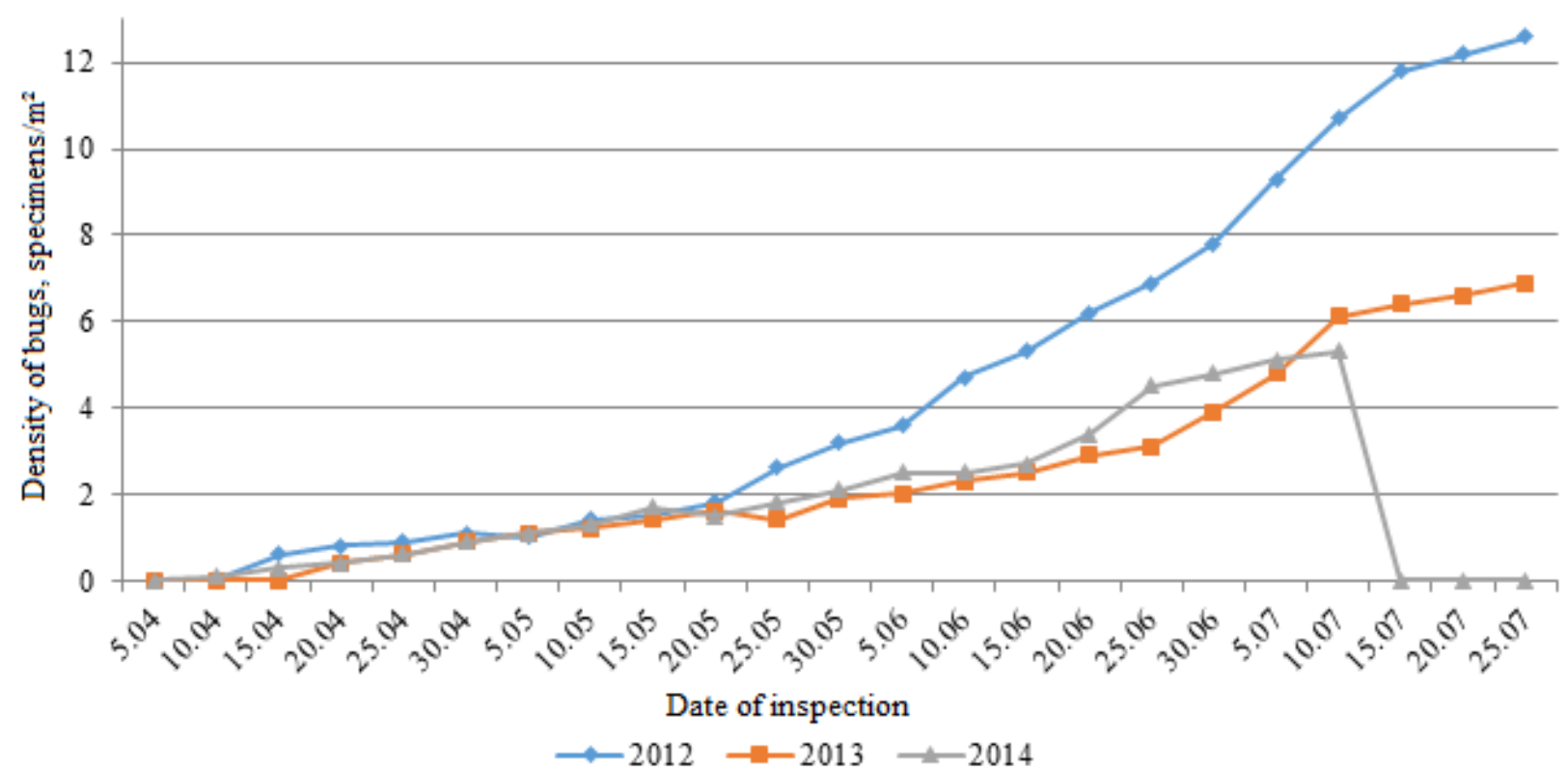

Fig. 2. Seasonal dynamics of cruciferous bugs' number on spring rape (here and then data for Educational, Research and Production Centre "Research Field" of Kharkiv National Agrarian University named after V.V. Dokuchaiev in 2012-2014 
We registered that the peak of the cruciferous bugs' number on spring rape was from the middle of June to the second decade of July in 2012-2014 (Fig. 2).

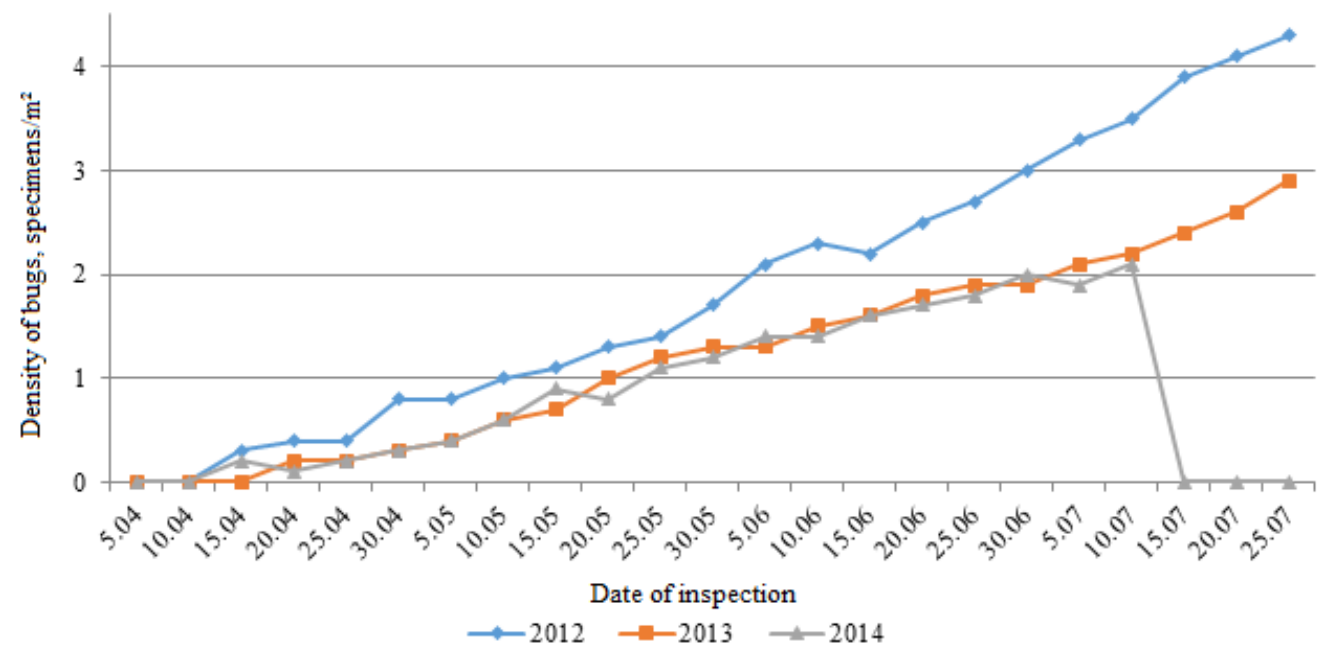

Fig. 3. Seasonal dynamics of cruciferous bugs' number on white mustard

During 2012-2014 the peak of the cruciferous bugs number on white mustard was between the middle of the first decade of May and the end of the first decade of July.

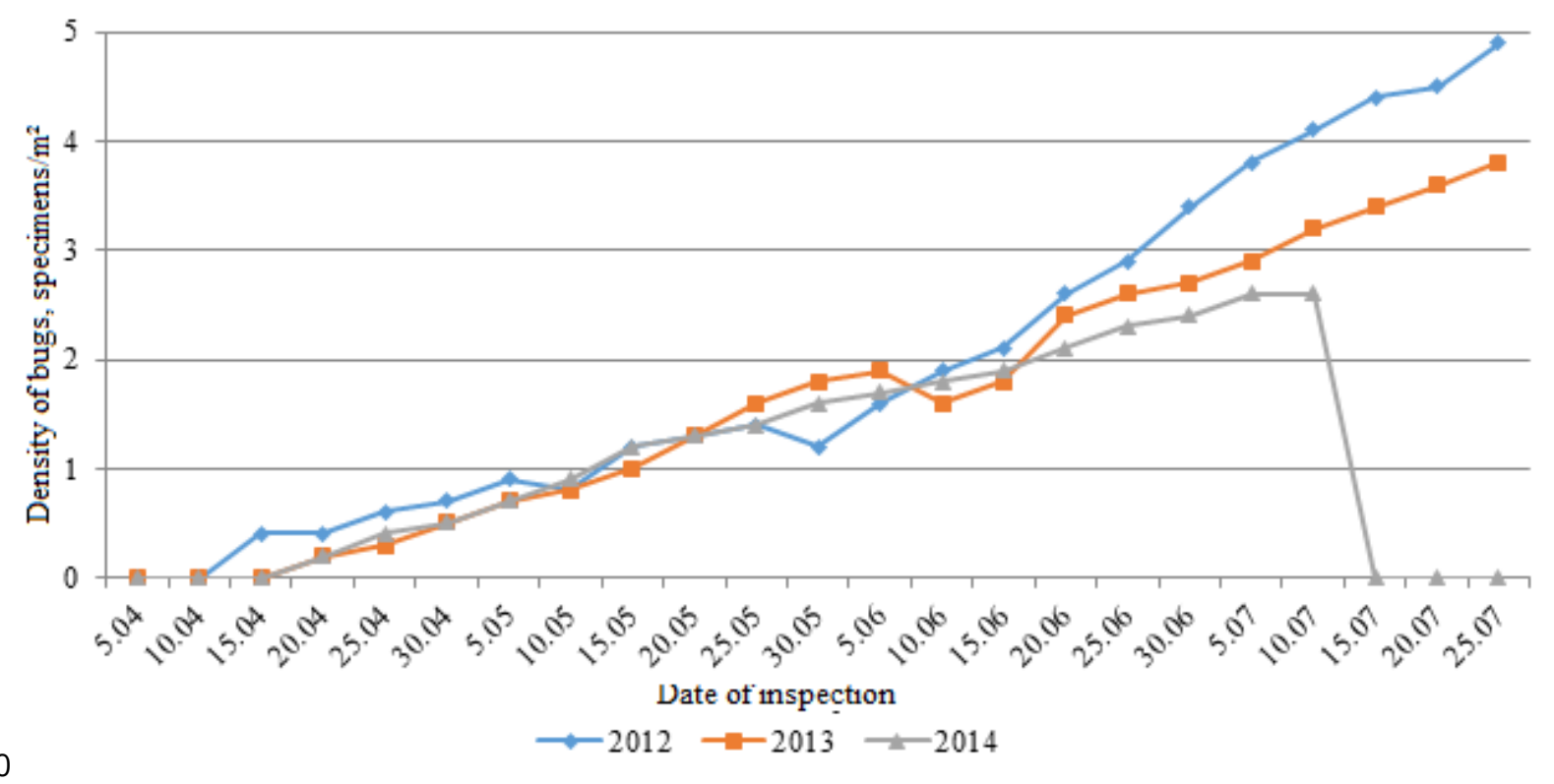

Fig. 4. Seasonal dynamics of cruciferous bugs' number on Chinese mustard

The peak of the cruciferous bugs' number on Chinese mustard (Figure 4) lasted 20 days, from the beginning of the third decade of June to the end of the first decade of July. The cruciferous bugs at the immature imago stage overwinter under the fallen leaves, in the parks, at the forest edges, on the beam slopes, on the roadsides, and in the gardens. We determined the cruciferous bugs' density in the forest belts around the experimental field and at the dendrological park's edge in the autumn and spring inspections of 2012-2014 (Table 5). The highest density of the cruciferous bugs in the hibernation places is concentrated in the forest belts and is amounted to about 3.1 specimens $/ \mathrm{m}^{2}$ (Table 5). There are much fewer bugs at the forest edge, and their number is about 1.9 specimens $/ \mathrm{m}^{2}$.

Table 5. The density of cruciferous bugs in hibernation places in 2012-2014

\begin{tabular}{lcccccc}
\hline \multicolumn{1}{l}{ Species } & \multicolumn{6}{c}{ Number of bugs by the years, specimens $/ \mathrm{m}^{2}$} \\
& \multicolumn{2}{c}{2012} & \multicolumn{2}{c}{2013} & \multicolumn{2}{c}{2014} \\
& forest belt & forest edge & forest belt & forest edge & forest belt & forest edge \\
\hline Cabbage bug & 1.0 & 0.7 & 3.0 & 1.4 & 2.1 & 1.8 \\
Rape bug & 0.4 & 0.5 & 1.2 & 0.6 & 1.6 & 0.7 \\
$\begin{array}{l}\text { Mustard bug } \\
\text { Total number of }\end{array}$ & 0 & 0 & 0 & 0 & 0 & 0 \\
bugs per $\mathrm{m}^{2}$ & 1.4 & 1.2 & 4.2 & 2.0 & 3.7 & 2.5 \\
\hline
\end{tabular}




\section{Conclusions}

1. The cruciferous bugs (Eurydema spp.) are a counterpart of the complex of the main pests of the cabbage crops generative organs in the Eastern Forest-Steppe of Ukraine. three species present the cruciferous bugs: painted or harlequin (cabbage) bug (Eurydema ventralis Kol), pentatomid rape bug (E. oleraracea L.) and mustard bug (E. ornata L.). The dominant species is a cabbage bug. The mustard bug dominated only in 2007, and since 2012 it has not been detected in the records.

2. The largest number of wintering bugs was concentrated in the forest belts, near which there were the crops of spring oilseeds and cabbage plants and the seeds of white cabbage. In 2012-2014 the density of wintering imagines of the cabbage bug was 1.7-4.4 specimens $/ \mathrm{m}^{2}$, and the density of the rape bug was $0.9-2.3$ specimens $/ \mathrm{m}^{2}$ of the forest floor.

3. The imagines of the overwintered bugs populated the cabbage seeds as a trap crop, and then they populated the sprouts of spring rape and mustard. At the Educational, Research and Production Centre "Research Field" of Kharkiv National Agrarian University named after V.V. Dokuchaiev, the density of the cruciferous bugs on the seeds of white cabbage of Kharkivska 105 variety was 19.0-30.7 specimens per plant at the beginning of the populating of spring oilseed cabbage crops. The maximum density of the cruciferous bugs in the phenophase of the yellow bud on the crops of spring oilseed cabbage plants was the following: $4.5 \pm 1.45$ specimens $/ \mathrm{m}^{2}$ of cabbage bug was found on spring rape of Ataman variety, $4.0 \pm 1.83 \mathrm{specimens} / \mathrm{m}^{2}$ on white mustard of Carolina variety and $3.5 \pm 2.65$ specimens $/ \mathrm{m}^{2}$ on the Chinese mustard of Tavrychanka variety; and the density of the rape bug was $0.7 \pm 0.23$ specimens $/ \mathrm{m}^{2}, 0.5 \pm 0.23$ specimens $/ \mathrm{m}^{2}$ and $0.5 \pm 0.3$ specimens $/ \mathrm{m}^{2}$ respectively.

4. At the state enterprise "Research Farm "Elitne" the maximum density of the cruciferous bugs in the phenophase of the yellow bud on spring rape of Ataman variety was $6,0 \pm 0,9$ specimens/ $\mathrm{m}^{2}$, on white mustard of Carolina variety it was $5.7 \pm 0.85$ specimens $/ \mathrm{m}^{2}$ and on Chinese mustard of Tavrychanka variety the average density was $5.3 \pm 0.9$ specimens $/ \mathrm{m}^{2}$.

5. In 2015, the highest number of cabbage and rape bugs is concentrated on the seeds of white cabbage plants at noon at a density of 22.3-30.7 specimens/plant, and the lowest number of them was found at 8 AM, and it was 17.9-28.5 specimens/plant. The maximum density of 51-60 specimens/plant was at noon.

6. At the Educational, Research and Production Centre "Research Field," the beginning of populating spring rape of Ataman variety by the bugs took place in the phenophases of 3-4 pairs of true leaves, namely during the rosette formation. The sum of the active temperatures was $411.8,299.2$, and $106{ }^{\circ} \mathrm{C}$ on May 20, 2012, May 26, 2013, and April 30, 2014. The larval reappearance's beginning took place at the sum of the active temperatures of $687.9,668.5$, and $520.3{ }^{\circ} \mathrm{C}$, respectively. Depending on the annual climatic conditions, the cruciferous bugs' peak was observed from the second and third decades of June to the third decade of July. The highest density of the bugs was registered before harvesting.

\section{References}

Beleckij, E. N., Stankevich, S. V. \& Nemerickaja, L. V. (2017). Sovremennye predstavlenija o dinamike populjacij nasekomyh: proshloe, nastojashhee, budushhee. Sinergeticheskij podhod. Vesti HNAU im. V. V. Dokuchaeva. Ser. "Fitopatologija i jentomologija”, 1-2, 22-33. (in Russian).

Beleckij, E. N. \& Stankevich, S. V. (2018). Policiklichnost', sinhronnost' i nelinejnost' populjacionnoj dinamiki nasekomyh i problemy prognozirovanija, Vienna, Premier Publishing s.r.o. Vienna (in Russian).

Chajka, V. M. \& Polishuk, A. A. (2010). Na posivah ozimogo ripaku. Efektivnist riznih metodiv obliku chiselnosti dlya monitoringu entomofauni. Karantin i zahist roslin, 3, 5-7. (in Ukrainian).

Fasulati, K. K. (1971). Polevoe izuchenie nazemnih bespozvonochnyh. Moscow (in Russian).

Dospehov, B. A. (1985). Metodika polevogo opyta (s osnovami statisticheskoj obrabotki rezultatov issledovanij). Moscow. Kolos (in Russian).

Golovan, L. V., Klymenko, I. V. \& Stankevych, S. V. (2019). The inheritance of economically valuable features in the intraspecific hybridization of bean (Phaseolus L). Ukrainian Journal of Ecology, 9 (2), 156-169.

Kost, E. A. (1975). Spravochnik po klinicheskim laboratornym metodam issledovaniya. Moscow, Medicina (in Russian).

Megalov, V. A. (1968). Vyyavlenie vredietlej polevyh kultur. Moscow, Kolos (in Russian).

Metodika uchyota i prognoza razvitiya vredietelej i boleznej polevyh kultur v Centralno-Chernozyomnoj polose. (1976). Voronezh, Centralnochernozyomnoe kn. izdatelstvo (in Russian).

Nacionalnij standart Ukrayini (2003). Nasinnya silskogospodarskih kultur. Metodi viznachennya yakosti: DSTU 4138-2002. Kiyiv, Derzhspozhivstandart Ukrayini (in Ukrainian).

Nikiforov, A. M. \& Bezdenko, T. G. (1951). Metodicheskie ukazaniya po vyyavleniyu vreditelej i boleznej selskohozyajstvennyh rastenij. Minsk, Izd. AN BSSR (in Russian).

Omelyuta, V. P. (1986). Oblik shkidnikiv i hvorob silskogospodarskih kultur, Kiyiv, Urozhaj (in Ukrainian).

Puchkov, V. G. (1961). Fauna Ukrayini. Shitniki, 1(21), 338. (in Ukrainian).

Rekomendacii po obsledovaniyu selskohozyajstvennyh ugodij na zaselyonnost vreditelyami i zaselyonnost boleznyami (1975). Kiev, Urozhaj (in Russian).

Stankevich, S. V. \& Vilna, V. V. (2012). Vidovij sklad kompleksu hrestocvitih klopiv v umovah Harkivskogo rajonu. Dinamika bioriznomanittya. Lugansk, LNU im. T. G. Shevchenka (in Ukrainian).

Stankevich, S. V. \& Kava L. P. (2013). Shkidniki ripakiv ozimogo i yarogo u Shidnomu ta Centralnomu Lisostepu Ukrayini. Visnik HNAU im. V. V. Dokuchayeva. Seriya "Fitopatologiya ta entomologiya", 10, 163-168. (in Ukrainian).

Stankevich, S. (2015). Shkidniki hrestocvitih. The Ukrainian Farmer, 5 (65), 74-75. (in Ukrainian).

Stankevich, S.V., Beleckij, E.N. \& Zabrodina, I.V. (2019a). Ciklicheski-nelinejnaya dinamika prirodnyh sistem i problemy prognozirovaniya. Vankuver, Accent Graphics Communications \& Publishing. Vankuver (in Russian).

Stankevich, S.V. \& Zabrodina, I.V. (2016a). Ekonomichni porogi shkidlivosti osnovnih shkidnikiv silskogospodarskih kultur, Harkiv, HNAU, 24. (in Ukrainian).

Stankevich, S.V. \& Zabrodina, I.V. (2016b). Monitoring shkidnikiv silskogospodarskih kultur. Kharkiv, FOP Brovin O.V. (in Ukrainian).

Stankevych, S.V., Vasylieva, Yu.V., Golovan, L.V., Zabrodina, I.V., Lutytska, N.V., Nakonechna, Yu.O., Molchanova, O.A., Chupryna, Yu.Yu., Zhukova, L.V. (2019b). Chronicle of insect pests massive reproduction. Ukrainian Journal of Ecology, 9 (1), 262-274. 
Stankevych, S. V., Yevtushenko, M. D. \& Zabrodina, I. V. (2019c). V.V. Dokuchaiev Scientific School of Kharkiv National Agrarian University and development agricultural entomology in XIX-XXI centuries. Ukrainian Journal of Ecology, 9 (2), 156-169.

Stankevych, S. V., Yevtushenko, M. D. \& Zabrodina, I. V. (2020a). Pests of oil producing cabbage crops in the eastern forest-steppe of Ukraine. Ukrainian Journal of Ecology, 10(5), 223-232.

Stankevych, S.V., Yevtushenko, M.D. \& Vilna, V.V. (2019d). Integrated pest management of flea beetles (Phyllotreta spp.) in spring oilseed rape (Brassica napus L.). Ukrainian Journal of Ecology, 9(3), 198-207.

Stankevych, S. V., Baidyk, H. V. \& Lezhenina, I.P. (2019e). Wandering of mass reproduction of harmful insects within the natural habitat. Ukrainian Journal of Ecology, 9(4), 578-583.

Stankevych, S. V., Yevtushenko, M. D. \& Vilna, V. V. (2019f). Efficiency of chemical protection of spring rape and mustard from rape blossom beetle. Ukrainian Journal of Ecology, 9(4), 584-598

Stankevych, S. V., Yevtushenko, M. D. \& Vilna, V. V. (2020b). Host plants as reservoirs of the main oil-producing cabbage crops pests in the eastern forest-steppe of Ukraine. Ukrainian Journal of Ecology, 10(6), 243-248.

Stankevych, S.V., Biletskyj, Ye.M. \& Zabrodina, I.V. (2020c). Prognostication in plant protection. Review of the past, present and future of nonliner dynamics method. Ukrainian Journal of Ecology, 10(4), 225-234.

Stankevych, S.V., Biletskyj, Ye.M. \& Zabrodina, I.V. (2020d). Cycle populations dynamics of harmful insects. Ukrainian Journal of Ecology, 10(3), $147-161$.

Stankevych, S.V., Biletskyj, Ye.M. \& Zabrodina, I.V. (2020e). Prognostication algorithms and predictability ranges of mass re production of harmful insects according to the method of nonliner dynamics. Ukrainian Journal of Ecology, 10(1), 37-42.

Stankevych, S.V., Biletskyj, Ye.M. \& Zabrodina, I.V. (2020f). Prognostication in plant protection. Review of the past, present and future of nonliner dynamics method. Ukrainian Journal of Ecology, 10(4), 225-234.

Stankevych, S.V., Yevtushenko, M.D. \& Vilna, V.V. (2020g). Dominant pests of spring rape and mustard in the eastern Forest- Steppe of Ukraine and ecologic protection from them: monograph, Kharkiv, Publishing House I.Ivanchenko.

Stankevych, S.V., Biletskyj, Ye.M. \& Golovan, L.V. (2020h). Polycyclic character, synchronism and nonlinearity of insect population dynamics and prognostication problem: monograph. Kharkiv, Publishing House I. Ivanchenko.

Tribel, S. O. (2001). Metodiki viprobuvannya i zastosuvannya pesticidiv, Kiyiv, Svit (in Ukrainian).

Turenko, V. P., Bilyk, M. O. \& Zhukova, L. V. (2019). Pathogens of spring barley on abiotic factors in the eastern forest-steppe of Ukraine. Ukrainian Journal of Ecology, 9 (2), 179-188.

Vilna, V. V. (2013). Dinamika chiselnosti klopiv rodu Eurydema (Hemiptera: Pentatomydae) na posivah kapustyanih kultur u NNVC «Doslidne pole» HNAU im. V. V. Dokuchayeva. Visti Harkivskogo entomologichnogo tovaristva, XXI, 2, 63-66. (in Ukrainian).

Vilna, V. V. \& Stankevich, S. V. (2013). Hrestocviti klopi ta obmezhennya yih shkidlivosti u NNVC “Doslidne pole” HNAU im. V. V. Dokuchayeva. Visnik HNAU im. V. V. Dokuchayeva. Seriya "Fitopatologiya ta entomologiya", 10, 64-70. (in Ukrainian).

Vilna, V. V. \& Stankevich, S. V. (2014). Hrestocviti klopi ta ripakovij kvitkoyid - osnovni shkidniki generativnih organiv olijnih kapustyanih kultur u Shidnomu Lisostepu Ukrayini. Visti Harkivskogo entomologichnogo tovaristva, XXII, 1-2, 5-11. (in Ukrainian).

Vilna, V. V., Yevtushenko, M.D. \& Stankevich, S. V. (2015). Rasteniya-rezervatory hrestocvetnyh klopov. Zemledelie i zashita rastenij, 1 (98), $43-45$. (in Ukrainian).

Yevtushenko, M. D., Fedorenko, N.V. \& Stankevich, S.V. (2009). Efektivnist insekticidiv pri zahisti yarogo ripaku vid blishok (Phylotretta Spp.) ta klopiv (Eurydema Spp.) do cvitinnya. Visnik HNAU im. V. V. Dokuchayeva. Seriya "Entomologiya ta fitopatologiya", 8, 39-43. (in Ukrainian).

Yevtushenko, M. D. \& Vilna, V. V. (2014). Vidovij sklad sisnih shkidnikiv ripaku yarogo i girchici ta osoblivosti biologiyi hrestocvitih klopiv. Visnik HNAU im. V. V. Dokuchayeva. Seriya "Fitopatologiya ta entomologiya", 1-2, 70-80. (in Ukrainian).

Yevtushenko, M. D., Stankevich, S.V. \& Vilna, V.V. (2014). Hrestocviti blishki, ripakovij kvitkoyid na ripaku yaromu j girchici u Shidnomu Lisostepu Ukrayini. Kharkiv (in Ukrainian).

Yevtushenko, M. D., Vilna, V. V. \& Stankevich, S. V. (2016). Hrestocviti klopi na ripaku yaromu j girchici u Shidnomu Lisostepu Ukrayini. Harkiv, FOP Brovin O.V. (in Ukrainian).

Zhukova, L. V., Stankevych, S. V. , \& Turenko, V.P. (2019). Root rots of spring barley, their harmfulness and the basic effective protection measures. Ukrainian Journal of Ecology, 9 (2), 232-238.

\section{Citation:}

Stankevych, S.V., Yevtushenko, M.D., Vilna, V.V., Matsyura, A.V., Zabrodina, I.V., Lezhenina, I.P., Baidyk, H.V., Filatov, M.O., Sirous, L.Ya., Yushchuk, D.D., Melenti, V.O., Lutytska, N.V., Kolomiiets, Yu.O., Molchanova, O.A. (2021). Species ratio in the complex of the cruciferous bugs and seasonal dynamics of the population number. Ukrainian Journal of Ecology, 11 (1), 38-45.

(cc) EY This work is licensed under a Creative Commons Attribution 4.0. License 